\title{
Argentina - China. Sustainable development for a better future
}

\author{
Artem Samorodov* \\ MGIMO University, School of Governance and Politics, 119454 Moscow, Russia
}

\begin{abstract}
Argentina is considered one of the fastest developing countries in Latin America. However, since 2015, the country has been trying to get out of the economic crisis, which has significantly worsened by 2019 . Meanwhile China's relations with geographically and culturally distant continents, such as Latin America, are widely seen as a part of Chinese government's drive to establish itself as a global leader, as well as to secure new markets and resources for its sustainable growth. Even the distance between regions is not a significant obstacle to the sustainable development of relations. This article will discuss the relations between the People's Republic of China and the Argentine Republic. The author focuses on the economic, investment and energy aspects of sustainable development of bilateral relations. The objective was to establish the format of bilateral relations between Argentina and China starting in 2015 and ending in 2020. It can be concluded that the relations between Argentina and China are a dynamically developing example of mutually beneficial sustainable development of the two countries and such relations can be used by Argentina in order to overcome the crisis and for further prosperity of this beautiful country.
\end{abstract}

\section{Introduction}

The relevance of the chosen topic is due to the growing influence of China both in the world in general and in the Latin American region in particular. Despite the difficult economic situation in Argentina, China can help significantly strengthen the economy by investing in the country and implementing various projects together. At the same time, Argentina is a gateway for China to strengthen its influence in the region, as well as helping China to pursue a diversified policy in Latin America. Thus, this is a mutually beneficial partnership that benefits both sides and will only grow stronger in the future.

The objective of the study was to establish the format of bilateral relations between China and Argentina in the period from 2015 to 2020.

The objective of the study determines the solution of the following tasks: to analyze the relations between Argentina and China in the period from 2015 to 2020; to study the fundamental bilateral documents; to examine the impact of China on the Argentine economy.

The object of the study is the Chinese vector of Argentina's foreign policy.

\footnotetext{
* Corresponding author: artyom.samorodov@gmail.com
} 
The subject of the study is the influence of Chinese politics on Argentina.

The author hypothesizes that the establishment of good relations with China in order to attract investment and implement different economic, energy and infrastructure projects can help Argentina to overcome current economic crisis.

\section{Methods}

Content analysis of documents, news and literature on the research topic; description of events that occurred in the period from 2015 to 2020; synthesis of all the information received.

\section{Results}

The period from 2015 to 2020 was a turning point in the history of relations between Argentina and China. A large number of agreements were concluded in various fields, such as the economy, infrastructure, energy and politics. It is also safe to say that the relations between China and Argentina are mutually beneficial, since China makes a large amount of investment both in the economy of Argentina and in its infrastructure development, while there is no threat to its national sovereignty. In turn, Argentina serves as a «bridge» for China to Latin America in order to further extend its political and economic influence.

\section{Discussion}

Argentina's relations with the People's Republic of China have always been interesting. First of all, because China can be considered as a symbol of a pragmatic and subtle policy (that is, a symbol of what Argentina is striving to be). While remaining neutral in most cases, but with clear national priorities, China is the fastest growing economy in the world.

During the presidency of Nestor Kirchner and then of Cristina Fernandez de Kirchner in Argentina relations between the two countries can be undoubtedly called warm and friendly. China was the second export/import partner for Argentina, second only to Brazil, but significantly ahead of the United States and the Russian Federation. Friendly relations can be fully justified by the ideological component. In 2015, Cristina Fernandez de Kirchner signed a number of business agreements with China. Among them, it is particularly worth highlighting the contracts for the joint construction of two nuclear power plants and two hydroelectric power plants for more than $\$ 15$ billion. [1]

After the election of Mauricio Macri, who is focused on developing relations with the West, ties with China were threatened with a partial freeze.

But despite the growing tensions between Washington and Beijing, Macri has built friendly relations with both powers. He was welcomed with open arms at international forums such as the G20 and the World Economic Forum in Davos. In May 2017, M. Macri participated in the Belt and Road Forum in Beijing. Chinese President Xi Jinping welcomed it, saying that «Latin America is a natural extension of the 21st century Maritime Silk Road», while welcoming Argentina's support and participation in the Belt and Road Initiative (BRI). As of 2018, there were more than 50 Chinese companies operating in Argentina, including Huawei, ZTE, Shanghai SVA, China TCL Group, Nanjing Jincheng, Industrial and Commercial Bank of China (ICBC), and the People's Bank of China.

The first meeting of the two leaders, Mauricio Macri and Xi Jinping, took place in April 2016. The two leaders met in the United States.

The main goal was to state that all relations should be fully open and transparent, hinting that the signed agreements with Cristina Fernandez de Kirchner may have violations. In 
particular, it refers to the construction of dams and nuclear power plants in Argentina. [2] The same situation has arisen in relation to Russia.

However, China has firmly and clearly stated that everything signed with Argentina is open, transparent and in accordance with the law. After that Argentina had no doubts about the legality of the agreements with the Chinese part. In this case, China has taken a tougher stance on protecting its investments than Russia. While the Russian side did not make clear and tough statements regarding the absence of any violations in the conclusion of significant contracts, the Chinese side quite clearly stated that all transactions, agreements and contracts concluded with the previous administration are legitimate. Otherwise, Argentina could lose a huge amount of investment. Therefore, in this case, it seems that on the part of Mauricio Macri and his administration, such a move seemed more like a political curtsey towards the West, but did not have a clear motive to break the agreements with the People's Republic of China.

The next meeting was held in September 2016 during the G20 summit in Hangzhou.

Xi Jinping said that China and Argentina are leading countries with emerging markets, that the countries are comprehensive strategic partners and should deepen cooperation and implement joint development. [3] It was noted that China is pleased with the current favorable trend in the development of bilateral relations, and that China is ready to make joint efforts with Argentina to further develop these relations.

The leaders also identified crucial points of contact: the creation of favorable conditions in the field of trade, the optimization of trade structures, the development of balanced bilateral trade, the implementation of projects in the fields of railways, hydropower, nuclear energy, and financial cooperation. The humanitarian component is also important: culture, science, technology, tourism, sports.

Based on the selected areas of cooperation, it is safe to say that China and Russia are competitors in the "Argentine market», and quite strong. Where each side has its own advantages, which Argentina, being pragmatic, is very actively ready to use. On the part of Russia, among others, it is possible to distinguish the political weight on the world stage in terms of being a direct parity antipode of the United States; on the part of China, this is obviously economic weight, investment and financial opportunities. The attempt to establish profitable relations with various competing countries is a reflection of Argentina's efforts to build a pragmatic and subtle policy.

The next meeting took place on May 14, 2017. Mauricio Macri arrived on an official visit to China. And during this visit, a large number of agreements were signed.

The main document developed by the parties is the Protocol of the meeting of the Second Permanent Bilateral (Bi-national) Commission of the Argentine Republic and the People's Republic of China. [4] (the commission was established in 2015.)

It is emphasized that both sides confirmed their desire to deepen the comprehensive strategic partnership.

Argentine-Chinese diplomatic relations date back 45 years.

The document notes that during the meeting, an important consensus was reached on strengthening bi-national ties. Both sides expressed their respect for the principle of sovereignty, saying that China is unitary and indivisible, and the Malvinas Islands are the legitimate territory of Argentina. The Bilateral (bi-national) Commission, the Joint Commission on Economic Cooperation, the Joint Commission on Trade, and the Committee on Political Dialogue between the Congresses of the two countries will play an important role in the relations between the two states.

The parties signed agreements on strengthening relations between foreign ministries and institutions that train professionals in the field of international relations [5], they also agreed to develop relations between representatives of the scientific community working in the field of international relations. 
The countries agreed to strengthen ties within organizations and forums, especially within the framework of the CELAC-China forum. This shows China's interest not only in Argentina, but also in developing ties with the entire Latin American region.

The document also refers to military cooperation between the two countries. It will be conducted in relation to the Antarctic research. The parties will also exchange experience, equipment and information. In addition, by deepening military cooperation, the countries will jointly conduct officer training and exchange between military training centers.

China and Argentina agreed to promote scientific and technical cooperation, joint research, and information exchange.

Both Sides said that cooperation in the field of science and innovation would develop. The priority areas for joint activities are: agricultural food; research and development in industries based on renewable energy sources and bioenergy; nanotechnology; biotechnology; biomedicine; information technology. It is noted that a joint project on the development and construction of radio telescopes is already underway.

As for cooperation in the field of agriculture, special attention will be paid to fishing, animal husbandry, modernization of the agro-industry and, in general, food security of the two countries. Argentina and China have signed a strategic action plan for cooperation in the field of agriculture for the period 2017-2022. [6]

Within the framework of cultural interaction, theaters, art groups and artists will participate in festivals and international fairs organized on each other's territory.

The two countries agreed to open a Chinese cultural center in Argentina, which will promote the Chinese language and Chinese culture and will be responsible for preparing Chinese cultural events in Argentina. [7]

Under the current agreement on cooperation in the peaceful use of nuclear energy, the parties will continue to build components for Argentine nuclear power plants. The Chinese side, together with the Argentine side, will participate in the construction and modernization of pipelines and water pipes on the territory of the latter.

There is also a point about cooperation in the space sphere: both sides positively assessed the completion of the construction of the Chinese reconnaissance station in the Argentine province of Neuquen. Previously, it was stipulated that Argentina would get access to strategically important information from Chinese reconnaissance satellites. The two countries also agreed to further cooperate in this area.

Regarding the investment sector, the document says that the Argentine side has expressed its intention to become a member of the Asian Infrastructure Investment Bank, which is considered as a replacement for the IMF (International Monetary Fund) and the World Bank. [8]

This will allow Argentina to significantly expand its funding opportunities for projects, primarily in the field of infrastructure.

Speaking more specifically about cooperation in the field of renewable energy, Argentina and China signed a contract for the construction of three photovoltaic power plants in Jujuy Province. The agreement was signed by Jujuy Provincial Governor Gerardo Ruben Morales and PowerChina President Wang Zhiyong. Expected investment is about $\$ 390$ million. It will produce more than 215 gigawatt-hours of clean energy per year, equivalent to the consumption of 100,000 households. [9]

The main event in terms of bilateral relations was the signing of a five-year plan for comprehensive Argentine-Chinese cooperation in the field of infrastructure. [10]

The plan is aimed at defining the principles, goals and priority areas of cooperation in the field of infrastructure. The cooperation will cover the following areas:

- transport (railway and automobile) infrastructure: construction of a new one, modernization of an existing one, reconstruction of a non-functioning one, as well as maintenance of vehicles; 
- port infrastructure: construction of ports and docks, repair of ships and equipment;

- hydropower: design and construction of facilities and equipment, their installation and supervision of their operation;

- nuclear power: design and construction of projects, production of equipment, maintenance of new and existing equipment, production of nuclear fuel;

- telecommunications: construction and operation of communication networks, including fixed broadband Internet access, expansion of the capacity of key communication networks, provision of $4 \mathrm{G}$ wireless network.

This document also includes the entire list of priority projects:

- Restoration of the San Martín railway system.

- Restoration of the Roca freight rail system.

- Restoration of the Mitre Freight railway system.

- Restoration of the Urquiza rail freight system.

- Restoration of the Belgrano railway freight system.

- Modernization of the Buenos Aires passenger rolling stock.

- Construction of power units at nuclear power plants.

- Construction of the Jujuy photovoltaic power plant «Cauchari».

- Construction of the hydroelectric power plant «El Tambolar».

- Construction of the hydroelectric power plant «Chihuído».

- Construction of the hydroelectric power station «Potrero del Clavillo».

- Construction of the Cerro Arauco wind farm.

- Construction of the hydroelectric power station «Los Blancos».

- Dredging of the river «El Salado».

- Modernization of the electrical network of the «Kirchner y Cepernic» dam.

In total, the amount of signed agreements between Argentina and China amounted to more than $\$ 17$ billion. [11]

Following the talks, Mauricio Macri, in an interview with Clarin, called the meeting very good and productive, and also stressed the fact that Chinese companies are willing to invest in Argentina.

It is interesting to note that in 2019, for the first time in history, China supplanted Brazil, Argentina's largest trading partner. The Argentine Republic exported US \$ 74 million more to China than to the Brazilian market. In April 2019, Argentine exports to China reached \$ 509 million, an increase of 50.6\%. [12]

Some experts believe that the coronavirus pandemic contributed to this.

In 2020, China and Argentina agreed to build a large-scale Chinese pork production in Argentina, intended for the market of this Asian country. The agreement provides for an investment of almost $\$ 3.8$ billion and production of 882,000 tons of meat. [13]

Argentina and China also reached an agreement on the construction of a nuclear power plant in the province of Buenos Aires. [14]

The financing of the project will be in charge of a consortium of Chinese banks led by the Industrial and Commercial Bank of China (ICBC), through a loan of close to $\$ 8$ billion, which would cover $85 \%$ of the price of the reactor and will be It estimates that some 7,000 direct jobs will be created.

It should be noted that in recent decades, China has exported record amounts of capital to the rest of the world.

Its direct loans and commercial loans declined from almost zero in 1998 to more than $\$ 1.6$ trillion in 2018. This figure is equivalent to $2 \%$ of the world's GDP. But, unlike what happens in most countries, these capital flows do not come from their private sector.

These are national funds, that is, funds channeled through companies or financial organizations controlled by the State. 
Its main investment levers are the China Development Bank and the Export-Import Bank of China, and through these institutes the Asian giant has become the banker of Latin America.

The total financial liabilities of the five Latin American countries, which were the most indebted to Chinese state structures, amount to more than $\$ 133$ billion. [15]

Experts agree that official loans always have a strategic element behind them and help China gain political influence.

In Latin America, experts explain that Beijing's geopolitical goals are to ensure the supply of resources and raw materials in addition to developing new markets for its own goods.

\section{Conclusion}

Summing up all of the above, it can be said that the relations between Argentina and China is a dynamically developing example of mutually beneficial sustainable development of the two countries. And such relations can serve as an excellent «springboard» for Argentina to overcome the crisis and further prosperity of this beautiful country.

\section{References}

1. M. Borisov, A. Andreev Novyi vneshnepoliticheskii vektor Argentiny.Klio, 6, 126 (2017)

2. Mauricio Macri se reunió con el president de China en Washington. La Nacion., https://www.lanacion.com.ar/1885128-mauricio-macri-en-washington-reunion-con-elpresidente-de-china-y-discurso-en-la-cumbre-de-seguridad-nuclear

3. Si. Tszin'pin vstretilsya s prezidentom Argentiny Maurisio Makri, SIN'KHUA Novosti, http://russian.news.cn/2016-09/03/c_135657036.htm

4. Acta de la Segunda Reunión de la Comision Binacional Permanente entre la Republica Argentina y la Republica Popular China, http://tratados.mrecic.gov.ar

5. Memorándum de entendimiento entre el Instituto del servicio exterior de la nación del Ministerio de relaciones exteriors y culto de la República Argentina y la Universidad de asuntos exteriors de China y la Academia diplomática del Ministerio de Relaciones exteriors de la República Popular China sobre formación de funcionarios diplomaticos, http://tratados.mrecic.gov.ar

6. Plan de accion estratégico en materia de cooperación agrícola entre el Ministerio de Agroindustria de la República Argentina y el Ministerio de Agricultura de la República Popular China 2017-2022, http://tratados.mrecic.gov.ar

7. Acuerdo entre la República Argentina y la República Popular China sobre el Establecimiento deun centro cultural chino en la Argentina, http://tratados.mrecic.gov.ar

8. Declaración conjunta entre la República Popular China y la República Argentina. 17 de mayo de 2017, http://tratados.mrecic.gov.ar

9. Acta de compromise de acuerdos para la construcción de la planta de energía removable cauchari solar en la provincial de Jujuy de la República Argentina, http://tratados.mrecic.gov.ar

10. Plan Quinquenal Integrado China-Argentina para la Cooperacion en Infrastructura (2017-2021). 17 de mayo de 2017. URL: http://tratados.mrecic.gov.ar 
11. Mauricio Macri cenó con el president de China y firmó acuerdos por US\$ 17 vil millones, https://www.clarin.com/politica/mauricio-macri-ceno-presidente-china-firmoacuerdos-us-15-mil-millones-encuentro-bueno_0_B1qT2hYxb.html

12. M. Carmo, «ArgenChina» por qué China desplazo a Brasil como el mayor socio comercial de Argentina, https://www.bbc.com/mundo/noticias-america-latina53920060

13. El acuerdo con China para producir carne de cerdo prevé inversión de US\$ 3.800 millones, https://www.telam.com.ar/notas/202008/498399-el-acuerdo-con-china-paraproducir-carne-de-cerdo-preve-inversion-de-us-3800-millones.html

14. Avances para la construcción de la cuarta central nuclear con tecnología china, https://www.telam.com.ar/notas/202104/549805-central-nuclear-construccionchina.html

15. C. J. OrgazCuáles son los países de América Latina que más dinero le deben a China (y qué implicaciones tiene esa deuda, https://www.bbc.com/mundo/noticias-americalatina-50574118 